\title{
Voices of a Natural Prison: Tourism Development and Fisheries Management among the Political Ghosts of Pisagua, Chile
}

\author{
Sarah Keene Meltzoff, Michael Lemons, and Yair G. Lichtensztajn \\ Division of Marine Affairs \& Policy \\ Rosenstiel School of Marine and Atmospheric Science
}

\section{Introduction}

"Up in the old abandoned hospital building where four migrant fishermen's families have set up households, one of the wives has a turquoise triggerfish drying on her clothesline, calling it a piranha. She explains that this year, thanks to El Niño, marine life typically found more offshore or in tropical waters is appearing in Pisagua, while stocks they normally harvest have dwindled."

(Meltzoff, fieldnotes, 1998)

Caught between the sea and a cliff in one of the world's driest deserts, Pisagua's coastal landscape is being transformed by the ways people utilize its natural isolation and rich sheltered waters.

Turn-of-the-century Pisagua was a thriving nitrate transshipment port with five wharves and colonial-style wooden architecture. With the Depression and the demise of the nitrate world market, Pisagua diminished almost to a ghost town. While Iquique, ${ }^{1}$ the city $162 \mathrm{~km}$. to the south by road (see Map 1), expanded from a dusty frontier port to a flourishing city, Pisagua stagnated economically and suffered for decades as a prison base. Because of this, the name Pisagua nationally evokes images of political prisoners, mass graves, and torture. This reputation, combined with Pisagua's natural isolation and desolation at the end of a steep treacherous road, have deterred most people from moving to Pisagua. Few, save a small group of migrant fishermen, have been willing to live here without the amenities that modern Chilean society takes for granted, such as electricity, telephone, and paved roads. The extreme desert environment precludes the need for solid walls and roofs, allowing a number of fishing families to inhabit the decaying town's wooden ruins. They live rent-free, as title to these properties has grown increasingly unclear over the years.

These fishermen who have chosen the outpost of Pisagua as their main base of operation form a fluid community. As artisanal fishermen, they maintain a pan-Chilean fishing culture that relies on a migratory, multi-species fishing strategy for survival (Meltzoff et al., 2002). Their identity over time remains as migratory fishermen still linked to ports of origin, often in regions far from where they have settled. In the Pisagua desert

1. Iquique now has a Duty Free market zone, fishing and tourist industries, as well as major copper mining up in the interior. 
port, fishermen have come and declared this new place as home, and are fostering a sense of pioneering together. Pursuing the shellfish export market booms of the 1980's and 1990's, they largely settled in Pisagua to take advantage of the relatively low numbers of divers exploiting the abundant shellfish. They are heavily reliant on loco, a high-priced abalone-type shellfish which continues as the fundamental source of local income in Pisagua, despite national fishing bans on its harvest. The severity of the 1997-98 El Niño event severely damaged loco stocks. Exacerbated by local overfishing, this event has threatened the loco stocks and the ability of divers to depend on loco for their income. Locals debate whether or not loco will rebound. Recently, an Asian economic collapse caused a drop in shellfish prices, adding to the fishermen's problems. Interestingly, the fishermen consider these difficulties temporary. As in many fisheries, such changes are accepted as vicissitudes in the life of a fisherman (Palsson, 1994).

Despite some degree of transience, a core fishing population has lived in this isolated place for nearly a decade. However, recent government fisheries legislation has attempted to limit them to one region, anchoring them into stable communities. The overall government development plan to incorporate Pisagua into the core Chilean economy through tourism is beginning to reverberate within the community, and the fishermen's livelihood and sense of identity is now subject to change. The leader of the Junta de Vecinos, acting as the main member of his self-titled community organization, is the sole bridge between the fishermen and the government-sponsored tourist developers.

Adding to these concerns over the use of Pisagua's space are the desires of political activists. Remembering Pisagua's intermittent role over the years as a political prison, they come annually to pay homage to those who suffered here. On the last Sunday of every October, ex-prisoners and their families are prominent among the pilgrims on the romería to honor Pisagua's unmarked mass grave, where 19 bodies were recently exhumed. As members of the political left, they condemn overt attempts being made to eradicate this negative image of Pisagua by the more right wing interests of tourism developers. The Junta leader may play an important role here, too, in any effective action; in addition to acting as a liaison to blend both fishermen and government tourism agendas, he intimately shares the sentiments of the political activists.

This paper is the result of ethnographic fieldwork carried out by Sarah Keene Meltzoff in the north coast of Chile over a six-year period (1995-2000). ${ }^{2}$ It focuses upon the discordant nature of government development in regards to the fishermen living in Pisagua and the political activists associated with Pisagua, and how conflicts have evolved in the wake of inevitably shifting environmental, economic, and political conditions.

The analysis of these interrelating forces at play in Pisagua illustrates the power of the political ecology approach as defined by Neumann (1992) and Bryant (1992). In historical perspective, this approach views prevailing multilevel economic and political conditions as determinants of shifts in resource competition, control, and use (Abler 1990:1-30; Durrenberger 1996; Meltzoff 1995, 2000). Through this lens, we view Pisagua's various user groups (e.g., the Junta De Vecinos, political activists, government planners, fishermen, fisheries managers, and tourism developers) as stakeholders with competing environmental, economic, and political concepts of landscape, sacred space, and "paradise".

2. This fieldwork was generously funded by NSF and NOAA. 
To supplement this approach, we recognize the importance of environmental conditions -- especially the1997-1998 El Niño event -- and how this interacts with economic and political changes. Thus, our entire discussion is framed by three overlapping climate changes: environmental, economic, and political. This triangle of forces sets the stage for social change and contested patterns of resource use, including tourist developer's site appropriation (territorialization), which threaten to alter the fishermen's and political activist's relationship with Pisagua.

The multiplicity of conflicts inherent in such a dynamic setting defies simple linear analyses, which often fail to take into account the whole picture of human/environmental interaction. Thus, as a method of presenting the interwoven nature of forces involved in the past and future shaping of Pisagua, we will first lay down an historical account of Pisagua. We will journey from Pisagua's rise as a nitrate port, through its uses as a political prison, to its current state as an entity of multiple identities poised once again on the brink of large-scale change. Through this account, you will see the present and previous influences on the various groups which currently seek claims in Pisagua. With the facts laid out chronologically, we will then focus on specific conflicts. Thus, our method is to paint the ethnographic picture in its entirety before examining individual elements. Through this we hope to better demonstrate the complex interdependence of the various conflicts among stakeholders.

Through this breakdown, we hope to answer some specific questions concerning each of Pisagua's stakeholders: What different visions of "paradise" are held by each group of stakeholders? What are the fishermen's and political activists' rights and access to resources and space as defined by government fisheries management and government tourism plans? To what extent do the fishermen and political activists have a voice in these plans? What active roles can the fishermen and activists play in maintaining their identity needs in the face of core development, and how will each of these roles interact with the needs of the other stakeholders?

From these questions we move to more solution-oriented inquiries: What are the advantages/disadvantages of a grassroots approach to the development of Pisagua? How can we transform the grassroots role from that of mediator between competing core/ periphery interests to that of mutually beneficial fuser of previously competing core/ periphery interests? Through these inquiries, we propose that considerations of local space and identity are necessary for globalization to function; i.e., the marginalization of local identities and livelihoods does not simply undermine local interests - it may ultimately undermine long-term global economic interests. Of import are the roles of history and environment in determining an efficient and economic use of Pisagua. Local knowledge, livelihoods, and identities hold the keys to such success.

\section{Oasis on the Desert Shore: Historical Influences}

\section{Pisagua as Port}

At the mouth of the Tilliviche Gorge, circa 1520, the Spanish joined with the indigenous desert coastal fishermen - Chango - who navigated on rafts of inflated sea lion skin to run a contraband port. Although the gorge, with its geoglyphs depicting llama herding, had long been part of an Inca trade route, the Changos' partnership with the conquistadors marked an early incarnation of Pisagua as a port base - the place now called 
Pisagua Vieja. Unlike many sites along the desert coast, including Iquique, Pisagua had its own natural source of water, making it an attractive place to settle.

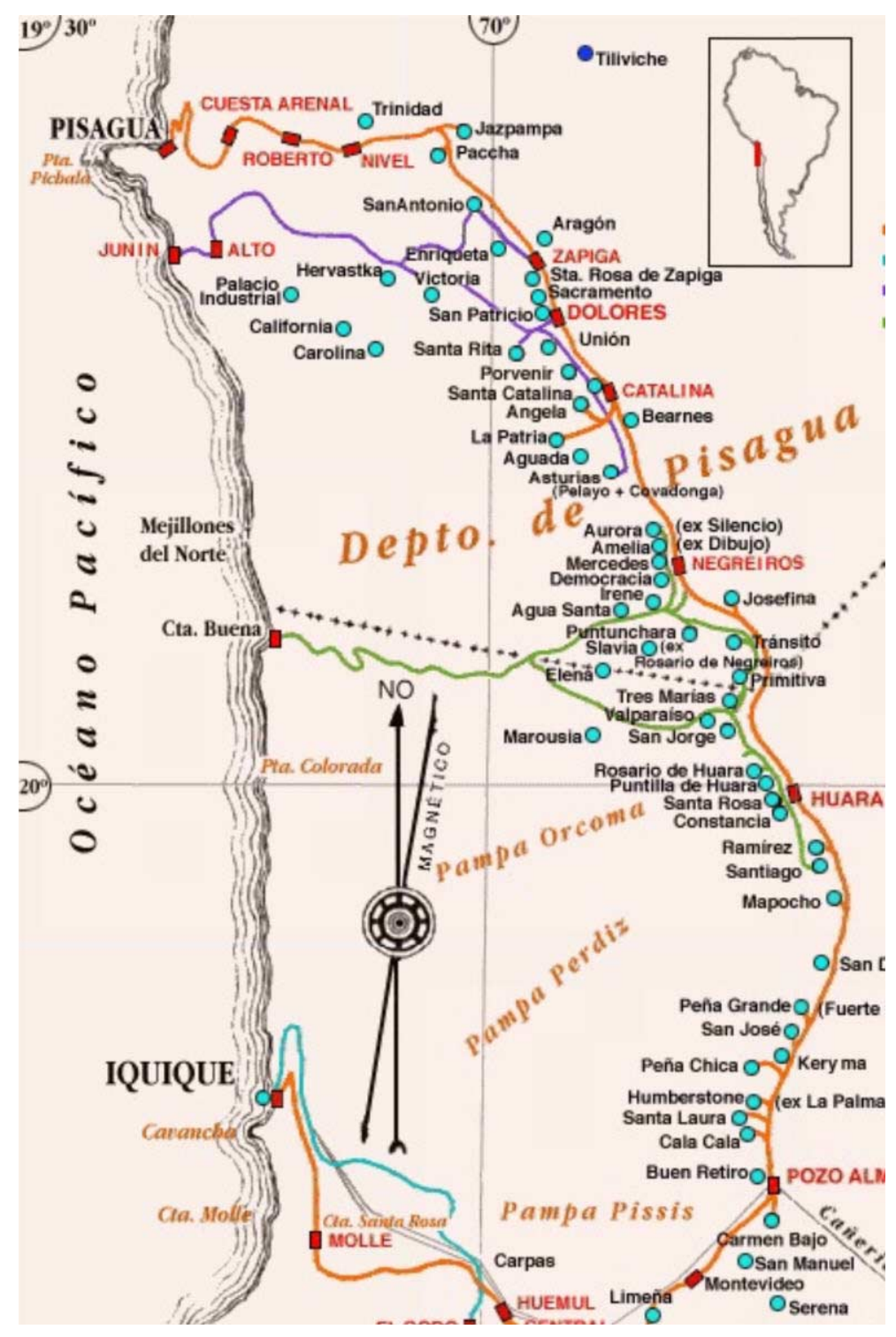

\section{Map 1. Department of Pisagua, Chile.}

When nitrate was first mined and exported from the region around 1830, Pisagua Viejo seemed a logical site at which to establish a nitrate port. However, by 1836, the settlement and port moved around the promontory to a more strategically protected position inside a 
bay (Guillermo Ross-Murray Lay-Kim, Iquique archivist/poet/historian, personal communication).

The whole dry northern pampas region above the coast, at the time part of Peru, was covered in nitrate mining operations. Nitrate was king. Peru chose Pisagua to be one of its key ports for export. A railroad line reached Pisagua in 1871, connecting some of the mines to the burgeoning port. Despite a devastating earthquake coupled with fires and a tidal wave that swept the town on 9 May $1877,{ }^{3}$ Pisagua's significance as a nitrate shipping port made it a major target in Chile's expansion campaign against Peru in the War of the Pacific (1879-1893) (Jo-Frazier 1998:255). Chile ultimately annexed the north, including the coastal ports of Arica, Pisagua, and Iquique. One famous and fierce battle, La Toma de Pisagua on 2 November 1879, is still commemorated today by the military. ${ }^{4}$

Paralleling strong Chilean economic growth at the turn of the 20th century, Pisagua's port trade and population levels peaked. Approximately 6,000 people inhabited Pisagua in its nitrate mining heyday (President of the Junta de Vecinos, personal communication). Nitrate for export flowed down to the port by railroad, while supplies, including locally caught fish, were carried on donkey back up into the pampas mines. Pisagua could now afford substantial wooden architecture and the trappings of society, such as a grand theater, a clock tower, a train station, and a hospital.

With the depletion of more northerly mines, by the 1920's, nitrate field sites and investments shifted southward. From the collapse of the nitrate industry, Pisagua's port population steadily declined. Pisagua, however, continued as a lesser transshipment port until the 1930's Depression struck, but did not completely close down as a port until Pisagua's railroad line closed in 1953.

Fishermen were essentially the only locals to persist here, and their fluid community absorbed migrants, including laid off miners and other unemployed. By the late 1950's, with the ultimate demise of nitrate in the region, more miners displaced by the closing of the mines up in the pampas moved to Pisagua and became fishermen, although the majority migrated to the bigger ports of Iquique and Arica. For the rest of the twentieth century, Pisagua devolved into the domain of a few fishing families inhabiting the ruins of past prosperity.

\title{
Pisagua as Political Prison
}

\author{
How will it end, How will it end? \\ In Pisagua's night, jail, chains, \\ Silence, the country debased, \\ and this bleak year, year of blind rats, \\ this bleak year of rage and rancor, \\ you ask, you ask me how it will end? \\ (Pablo Neruda, 1991: 199)
}

As income from nitrate decreased in the 1920's, the regional government contemplated alternative sources of revenue for Pisagua. With the port's decline and growing isolation from the national economy, the national administration stepped in and turned the town into

3. A previous tidal wave struck the town in 1868 .

4. Other War of the Pacific battles are commemorated on 21 May in Iquique and 7 June in Arica. 
a small penal fishing colony employing common prisoners (Jo-Frazier, 1998: 255-256). This launched Pisagua's identity as a natural prison, much to the chagrin of the local fishing community, who experienced a loss of dignity, as well as increased competition over marine resources. With the town's transformation, fishermen were the only steady local group to persist in Pisagua.

The fishermen would be forced to share their space multiple times as sequential Chilean leaders utilized Pisagua as a natural penitentiary for political prisoners. Their town became nationally synonymous with political repression. The first political use of Pisagua came briefly during the years 1927-1930 under the first presidency of Carlos Ibáñez del Campo, who established a policy of internal exile for political heretics and was noted for using Pisagua as a detention center for male homosexuals. ${ }^{5}$ In popular imagination, homosexuals have been a staple prisoner in Pisagua. ${ }^{6}$

Post-Depression, the prison aspect overtook the semi-abandoned town as more and more prisoners were shipped in through the 1940s and 1950s. Teitelboim's popular novel, Pisagua: La Semilla en la Arena ${ }^{7}$ is set in the Pisagua of 1948, during the second use of the town as a political prison camp. This time, President Gabriel González Videla exiled leftist political and labor leaders under his Law in Defense of Democracy. ${ }^{8}$

...Pisagua is more than a location or a "dead" city. It is the concentration camp, the community's living drama; it is a spirit, something that transcends geography and place, to become a word rife with political and human connotations.

Volodia Teitelboim (1972:7)

President Videla -- who is remembered as the architect of his birthplace, La Serena -could not resist constructing an elaborate prison whose two-story administrative front section is of Oregon pine ${ }^{9}$ in Georgian neoclassical style. By 1951, the small non-prisonrelated population in Pisagua numbered roughly one hundred. Alongside this enclave of fishermen, some prisoners had come with whole families, setting up camp in barracks and fishing for subsistence to overcome hunger.

The Minister of Justice, visiting Pisagua in 1945, had envisioned a bizarre and globally unprecedented national plan to turn Pisagua into a "Penal Fishing Industrial City" (JoFrazier, 1998: 259-260). But due to the influx of leftist prisoners, his plan was never implemented. Prisoners occasionally did become fishermen out of boredom, and they volunteered on projects out of desire to be occupied.

\section{Period of Industrial Hope: Fishmeal Plants circa 1962-65}

In Pisagua, like in Iquique and Arica, the Chilean government subsidized the establishment of a fish meal industry to replace the nitrate industry. ${ }^{10}$ Three fish meal companies brought in fishing vessels and set up processing plants in Pisagua. ${ }^{11}$ By 1963 ,

5. He was a rabid anti-homosexual with the ironic twist of having a homosexual son.

6. One debate at the time argued whether or not to contain and psychologically reform homosexuals at the site of national honor and military heroics in the War of the Pacific (Jo-Frazier,1998: 272273).

7. This translates as Pisagua: the seed in the sand.

8. His Popular Front was radical, then changed into anti-communist.

9. The region s historic building material was gleaned from old ship timbers. 
an influx of migrant workers into the fish meal industry briefly pushed Pisagua's population to its post-port peak at approximately 1500 inhabitants, of which only $5 \%$ were local fishing families.

The plants recruited labor from among the local fishermen, including the older men who had come down from the nitrate mines to fish. Pisagua proved too physically desolate and lacking in basic infrastructure for the companies to sustain a cost-effective business: the only road out of town was a narrow sand track climbing up hairpin turns; the cost of energy was high; and water was limited. Thus the plants, along with the government's hopes for a revived economy in Pisagua, were short-lived.

When the Pisagua fish meal plants closed, a number of the industrial workers moved on to the new copper mines, typifying an historic Chilean see-saw pattern between industrial fishing and mining. ${ }^{12}$ A critical move in 1971-72 took the governmental headquarters for the area, including the medical post, away from Pisagua, and moved the authorities and services up to the Pan-American highway in Huara. Pisagua was left behind with nothing but a small fishing community struggling on to retain its own livelihood.

\section{Pinochet and the Third Regime}

With General Pinochet's coup against President Allende in 1973, Pisagua reverted to its national role as prison. Of the three Chilean administrations to have utilized Pisagua's natural isolation as a place of political exile, this last era was the most brutal. The prison itself became the scene of the initial and cruelest treatment of Pinochet's prisoners. ${ }^{13}$ About 40 of 100 inhabitants were unwilling to endure, and fled town within days of the arrival of the first warship transporting prisoners. ${ }^{14}$ The seven fishing families -numbering about 60 people -- who did stay during Pinochet's regime needed to restructure their lives around the repressive atmosphere, and keep a low profile. One fisherman actively collaborated with the prison guards, currying favor through gifts of fish and occasional labor. As a result, he became the official controller of the permits required of locals to come and go from town. ${ }^{15}$ Still living in Pisagua, he is treated by the community with a degree of disdain.

Pinochet took the prison aspect of Pisagua to its pinnacle as a natural prison symbolizing inhumanity. 16 "...detainees were forced to crawl and lick the ground in front of military officials" (Constable, 1991, p. 33). Waves of prisoners inundated the town.

10. Between 1958-64, President Jorge Alessandre Rodr guez established a fishmeal industry to resuscitate the economy along the north coast, including Pisagua, through government financing..

11. The fishmeal companies were foreign-owned--Spanish and Norwegian. One of the three was never successfully started.

12. This labor cycle is evident in Iquique and Arica s industrial fishmeal industry. When overfishing, exacerbated by the 1997-98 El Ni o s impact on catches, caused a collapse, some of the fit and skilled workers (e.g. machine operators, engineers, chemists, secretaries) moved up to the higher paying, high altitude copper mines.

13. One famous incident leading up the 1973 coup, Pinochet brazenly denied entry for inspection purposes to leftist congressmen led by Senator (soon to be President) Allende (Constable, 1991).

14. For example, five divers and a pregnant woman who had been squatting together in the abandoned railroad building, escaped in their faluchos at dawn, heading north to Arica.

15. In 1979, there were still permits called salgo conducto required to exit the town. 
Rumors of mass killings were verified by the 1990 discovery of an unmarked mass grave whose contents included "cadavers with their hands bound and bullet holes in their heads" (Constable, 1991, p. 34). These cadavers were later shown on T.V. to the dismay and shock of conservative intellectuals who had supported Pinochet as a revolutionary and progressive military leader. This grave has become Pisagua's annual site of leftist political pilgrimage.

By 1984, Pisagua's use as a political prison had declined considerably. Some prisoners were housed in temporary barracks; others were kept in colonial buildings as well as upstairs in the once elegant theater. ${ }^{17}$ These political prisoners were allowed to roam and subsistence fish; the desert was an impenetrable wall. Despite continuing political repression, five of the seven fishing families who had stayed after the coup were still in Pisagua. They numbered 40 among the 500 total inhabitants who were primarily political prisoners, prison staff, and military. ${ }^{18}$ Through political family ties, an Arica businessman bought the run-down prison in this year for what was a token amount, ${ }^{19}$ then invested in six years of extensive renovation to convert the politically and architecturally important prison into a hotel.

\section{Boom Times and Loco Smuggling in Pisagua}

Pisagua's local population started to grow again after the worst of the Pinochet prison era had subsided. Divers felt freer to move to Pisagua, attracted by escalating shellfish prices resulting from increased Asian demand and market infrastructure. Buyers from Coquimbo in central Chile came to Pisagua to purchase the abundant locate (Thais chocalata) and loco (Choncholepas choncholepas)--a coveted shellfish that commands prices similar to those of abalone. ${ }^{20}$ Loco remained a core source of income for divers in Pisagua year-round despite government management regulations on seasons, size, quotas, and frequent blanket bans on all harvesting. The government instituted these regulations in response to unbridled loco harvests throughout Chile. Yet shellfish production in Pisagua continued to boom through 1990. Loco was the main target and most prized catch.

During the boom, a large number of shellfish divers arrived from Regions I - VIII and based themselves in caletas -- fishing ports -- south of Iquique and in Iquique itself. By the late 1980s, some had descended on Pisagua, ${ }^{21}$ attracted by its less heavily-exploited shellfish beds and bountiful fishing grounds. This pushed the local population up over 180 .

The infamous 1986 loco wars among artisanal fishermen -- caused by this rampant migration in search of loco -- motivated the national government to pass the section of the 1991 Fisheries Law that forces artisanal fishermen to register to fish within only one

16. During its years as a penal colony, Australia -- and Norfolk Island in particular -- had a similar meaning attached to it (Hughes, 1988).

17. Prisoners who were singers managed to stage a performance at the theater where purportedly Caruso -- the turn of the century opera star -- had elated a very different audience.

18. According to ex-prisoners, there were three or four fishermen who occasionally risked their own safety by secretly slipping a fish hook to prisoners around the town. But mostly, prisoners had to scavenge fishing line and hooks along the beach, or await hooks in the carefully censored care packages sent from loved ones.

19. 200,000 pesos.

20. Sea urchins were not yet being marketed and thus targeted.

21. The majority were from the five towns of Iquique, Arica, Taltal, Los Vilos, and Talcahuano. 
region. Once fishermen could no longer legally migrate between regions, they were obligated to settle, which allowed their families to join them. The majority of Pisagua's families arrived in Pisagua during this period; along with them came a number of fishermen who had initially fled Pisagua during the Pinochet regime...

With increased competition, continued ineffective government regulation of loco, and a dwindling loco stock, loco smuggling to Peru quickly established itself as the main source of income for Pisagua fishermen. Peru remains a conduit to the Asian shellfish market, a trampoline for all the illegally harvested and undersized loco that can be smuggled from Chile. Pisagua's advantage lies in being an out-of-the-way place where the length of the smuggling trip is relatively short. Currently, smugglers can set out from Pisagua with the now common 50 hp outboard motor at 4 p.m. and typically return by 9 a.m. the next morning, making the round-trip in less than a day. Some Pisagua divers prefer to sell directly to illegal buyers in Pisagua and thus accept seven times less profit for their loco in order to avoid the risks of smuggling. They let the buyers bear the burden of smuggling loco across the border to Peru by truck.

In 1997, loco yields in Pisagua had dropped to $100 \mathrm{~kg}$./day/boat, and consisted almost entirely of undersized loco. By 1998, loco were scant, and divers could not even harvest enough to merit a smuggling trip. Concerned about their loss of this staple, they blame overfishing but especially the warmer waters of the1997-98 El Niño event.

\section{Recurring Struggles with El Niño Events}

“During El Niño, divers understand sea lions' starvation and their increased aggression towards them to be as transient as the phenomenon, itself. In competition over the same food source, hungry sea lions maw at divers' mesh collection bags, and lunge at wiggling fish and octopus on spears, sometimes missing and grabbing an arm. The powerful 1997-98 El Niño decimated sea lions' food supplies up and down the coast, resulting in a shortage of pups at Pisagua's neighboring sea lion nursery and washing the corpses of large old males up onto shore. They see the sea lions' plight as a metaphor for their own cyclical struggle with nature. One group of fishermen in Pisagua especially identify themselves with sea lions, consuming their flesh and oil for sympathetic magic, to gain sexual prowess and heart strength."

(Sarah Meltzoff, fieldnotes, 1999)

When the 1997-98 El Niño event caused a number of anomalies in north Chile's marine environment, Chilean fishermen again resorted to migrating between caletas in response to resource availability and market conditions. They bemoaned three impacts of this El Niño event: the death of sea lions; loss of loco and other marine staples; and inordinately rough seas which limited fishing effort.

In 1997, at the start of this event, Pisagua was home to about 55 divers and one finfish fisherman with a falucho -- inboard artisanal fishing boat. Most had lived in Pisagua at least seven years. By 1998, with El Niño's turbulent seas, the resident diver population temporarily dropped to 40 . It is noteworthy that the community maintained a degree of resilience because of their ability to subsist and live virtually rent-free. Some fishing families were aided by cash sent from relatives working in the closest cities (Arica and Iquique). Providentially, the commencement of government road improvement projects coincided with peak El Niño trouble. This provided some alternative income for those who 
remained in Pisagua: in 1998, ten fishermen found short-term employment paving the main street and widening the cliff face road. ${ }^{22}$

Paradoxically, as Pisagua divers were seeking alternative income, 11 Iquique divers moved to Pisagua because coastal waters around Iquique are less sheltered than along Pisagua's relatively calmer coastline. But, far fewer faluchos than in other years came up to fish around Pisagua because this El Niño event was providing large catches of finfish south of Iquique, especially congrio (Genypterus spp.) and species of flounder.

Listening to local knowledge from the past, Pisagua's divers-- almost all of whom settled here after the major 1982-83 El Niño event -- tried to predict the impacts of the 1997-98 event as it was unfolding. However, they soon learned that El Niño events do not result in identical impacts each time. For example, during the1982-83 event, local divers noted that locate moved near shore to shallow waters and were quite plentiful. But during the 1997-98 event, divers felt that due to a combination of the event and overfishing, they were forced to go to deeper waters ( 30 meters) in order to find the now scarce locate. Most critically, by 1998, local divers could barely find enough loco to sustain their illicit market, a pillar of Pisagua's economy. Combined with unabating pressures from overfishing, it is unclear if stocks will ever totally rebound from the 1997-98 El Niño event, as divers hope.

Adding to the 1997-98 El Niño-induced shortages was an international market crisis. During the 1982-83 El Niño event, Chile's export market was still undeveloped. By the second event, the export market had been in place and booming for a decade, leaving Pisagua's export fisheries vulnerable to the effects of the Asian economic crisis. In 1998, locate prices plummeted to one third of their 1996 value. ${ }^{23}$ Octopus -- Pisagua's principal product after loco -- did not drop in numbers until October 1998, when catches fell by over 50\%. Yet between 1996 and 1998, octopus prices in Pisagua actually slid 60\% due to the Asian market drop.

Alarmed by the immediate uncertainty created by negatively synergistic environmental and global economic fluctuations, Pisagua's fishing community began to pin hopes on government plans to stabilize their livelihood.

\section{Pisagua Today}

Pisagua today is an interesting case study of competition between stakeholders. The three main players are: (1) government planners and tourist developers, (2) political pilgrims/activists, and (3) the fishermen. A focal point of this tension is the prison-turnedhotel, which can be treated as a territorial symbol of place/identity change for all three groups. A fourth group, the Junta, serves as a possible grassroots solution which could balance all this.

22. These ten road workers were seven dive assistants and three divers. Each earned about US\$15/ day.

23. Locate sold for about 200 pesos $/ \mathrm{kg}$. in 1996, 130 pesos $/ \mathrm{kg}$. in 1997, and 70 pesos $/ \mathrm{kg}$. in 1998 (US\$1/450 pesos). 


\section{Government Planning: The Delicate Act of Creating Paradise}

Having skirted the road construction by taking the harrowing detour down along the cliff face, Diputada Antonella Sciaraffia Estrada -- the national level senator from Iquique -- arrived in Pisagua's central plaza in November 1998. Her entourage included two professional clowns, a pair of singers, and a bevy of hair stylists from the city. While the women and younger divers took turns getting haircuts, the senator discussed her party's development plans for Pisagua (Gobernación Provincial de Iquique, 1998) with the locals.

(Meltzoff, fieldnotes, 1998)

In its post-Pinochet reincarnation, Pisagua's prison has been converted into an expensive hotel. The building dominates the central seaside plaza. The prison hotel's inner courtyard is a lush garden in the desert, with a caged parrot set in the middle -- the prison's one remaining captive. A museum wraps around the garden eaves; upstairs, a pool table fills a former communal cell block.

The owners say their hotel plays a prime role in the government plan to turn Pisagua into a tourist town. They say they will train fishermen to work in the tourist service industry, or in their words: "teaching locals what tourism is". They are beginning to hire fishermen to take tourists sport-fishing in their fishing boats and to see the sea lion nursery. The hotel also buys artifacts from the fishing families. When the rare desert rains of the 1997-98 El Niño event first washed bare pre-Columbian burial urns, fishermen enjoyed smashing them until they learned that money could be made by selling such artifacts to the hotel for its courtyard museum.

Paving and widening of the final stretch of the road descending to the seaside is a lynch pin in the government plan for regional social change (Programa Chile Norte, 1998). Other essential elements of the plan for infrastructure development include: building 40 government-subsidized homes for the locals; paving the main street; repairing the fishing wharf; building a crane on the dock; installing a small desalinization plant and a sewage treatment plant (utilizing arsenic); and improving pipelines for sewage and drinking water (Gobernación Provincial de Iquique, 1998). Adult technical training is also part of this package, including courses in scallop aquaculture for the fishermen. Also in the plan is a soccer field. A few local telephones are a recent arrival, and electricity finally came online in 1999.

Historic renovation of the whole town's wooden colonial architecture is aimed at fostering tourist appeal. The Plaza de Armas and the camping site, where most weekenders now stay, are identified as having the most touristic value. According to the Junta de Vecinos, all of Pisagua would be designated a zona típica -- historic zone -- with Pisagua Viejo, the original archaeological settlement site north of town and cemetery, declared a national monument. The faded guild and collapsing balconies of the municipal theater would be restored into a cultural center containing a library and a modernized auditorium. The Junta has started a campaign to protect the remaining old structures. They have posted a sign at the century-old train station forbidding further dismantling for lumber.

The government's explicit intent for these developments is twofold: (1) to create a tourist economy; and (2) to strengthen local identity and quality of life in a place where the majority of the meager population are fishing families, most of whom settled here around 1990. 


\section{Complications to the Plan: Pilgrims and Politics}

"The day before the romería on 25 October 1998, the troops marched out of Pisagua. Out of the pilgrimage bus and car windows, coming into Pisagua, we watched the line of soldiers filing through the high desert like ants, past the large circular modern-day geoglyphs made by bombs on the desert hillsides. The glyphs signify military occupation of this space."

(Meltzoff, fieldnotes, 1996)

Given Chile's prevailing prosperity and democracy, it seems unlikely that Pisagua will once more serve as a prison camp. Nonetheless, in today's democratic climate that can publicly condemn Pinochet, Pisagua stays a locus of political pilgrimage. Human rights activists come as political pilgrims annually to Pisagua to pay homage to those who suffered here. On the last Sunday of every October, the ex-prisoners and their families are prominent among the pilgrims on the romería to Pisagua's mass grave. Gathered around the empty rectangular grave, the crowd chants and waves banners to the triumvirate of the Chilean left: Pablo Neruda, Allende, and Victor Jara. Neruda's poetry and Jara's folk songs escalate emotions. National leaders of the "Mothers of the Disappeared" wear photos of slain loved ones pinned to their chests.

About a week after this demonstration, on November 2, the military come to Pisagua for their yearly celebration of the 1879 victory in the War of the Pacific. This ceremony takes place at a large stone monument situated half-way between the town and its cemetery, which sits next to the mass grave. The only constant military presence remaining in Pisagua is a seaside canteen restaurant by the police station, a recreational spot for officers now posted up in the pampas. But, for one month a year, army troops fulfilling their obligatory service still come to Pisagua to train in its desert, and are present for both memorials honoring distinct victories of spirit.

Pisagua holds a completely different political meaning for both groups coming to pay homage to their respective dead. While the military and their use of the Pisagua periphery has not posed conflict with the government plans for tourism, the pilgrims do voice considerable concerns:

"On this day, the prison hotel is tightly closed. The political pilgrims are protesting the overall conversion of the prison into a hotel. Instead they feel the former prison should be a shrine to the victims of political violence. They see this prison hotel as an act of sacrilege eradicating history, a sanitization of the past."

(Meltzoff, field notes, 1998)

Contested meanings of the prison have arisen because political activists are angered by the hotel and its museum. They want to take it over and convert the hotel into a commemorative museum. The owners, however, are only willing to sell it at a high price, believing in their business' ultimate profitability from the anticipated growth of tourism in Pisagua. 


\section{Voice of the Fishermen}

Backed up against the desert wall, the fishing families of Pisagua are expecting another cyclical natural event other than El Niño to strike. Predictions loom for a long overdue tidal wave. These are fueled by tales of the last tidal wave that swallowed Pisagua on 9 May 1877, brought on by a devastating earthquake. Pisagua's people were terrified by a wave pronouncement issued by an Iquique Catholic priest for 21 October. In anticipation, that day the divers stayed close to port. But, as they do when faced with El Niño predictions, they carried on with their day-today activities.

(Meltzoff, fieldnotes, 1999)

Brooding over possible recurrences of natural events, Pisagua's inhabitants speak of both tidal waves and the prolonged but less directly deadly El Niño events, as potential negative factors in their lives. But any predictions of these events - from scientific to spiritual sources - spawn only fear, not planning, since their coming is uncertain. The fishermen feel largely powerless in the face of these events. With regard to tidal waves, Pisagua's people can neither afford disaster insurance, nor move housing locations high up the hillside. With regard to El Niño, they know they cannot control the natural cycles, and are left to hope that loco and sea lion populations will rebound, or that events will occur farther offshore.

The fishermen consider themselves as well as the media to be equally fallible in predicting the variables vital to them: duration; intensity; whether the warm waters will come near shore; and exactly which species will thrive or die. When national and local media forecast El Niño events, their news is based upon conflicting reports obtained from over ten different groups paid to interpret NOAA climate forecasts. The fishermen themselves choose a wait-and-see tactic, relying on their own local knowledge and day-today observations to decide if, when, and where to harvest. Their predictions are informed by natural indicators -- such as the appearance of more tropical species like triggerfish.

Fishermen assume that the 1997-98 El Niño event will eventually play itself out, yet realize that there is no way to anticipate its impact on their livelihood. Though stocks were still in recuperation in 1999, loco empanadas -- hot stuffed pastry pockets -- were once again common fare at a fisherman wife's home-based restaurant. In their own opinion, divers could remain or even increase in numbers if loco stocks fully recover. In local consciousness, diving for loco is still their fundamental livelihood, regardless of the cyclical effects of El Niño, regardless of an openness to tourism.

Most fishermen view government planning for Pisagua's future with both a degree of skepticism and an innocent eagerness to be brought in from the periphery of Chile's economy. Yet the Pisagua fishing community maintains a short-term economic perspective, only envisioning benefits from the new infrastructure development. They have been most concerned with obtaining utilities and public services, yet haven't considered repercussions on their fishing livelihood. The same infrastructure that will enhance the quality of daily life may easily draw in more fishermen, leading to increased pressure on the resource base. The government's primary aims are to stimulate private investment in tourism and vacation home ownership; fisheries development plays second fiddle. Thus there is a disconnect between fishermen's livelihood and the livelihood they envision: fishermen simply don't anticipate the cost of living increasing with more services. 
Meanwhile, the government continues to play off the fishermen's fantasies of infrastructure.

Fishermen tend to remain relatively unengaged in struggles over political identity (Watts, 1993), and Pisagua is no exception. Though Pisagua is a veritable battleground for opposing political interests, the actual inhabitants of the town -- the fishermen -- stay out of the fray, and are conspicuously absent from the ongoing protests and romerías. This pattern has proved a successful survival tactic for decades: fishermen have been Pisagua's predominant non-prisoner population, and keeping a low profile has allowed them to persevere throughout the three prison periods.

Nonetheless, the political prison use of the town cast shame upon the fishermen especially when it impinged upon their identity and livelihood. For example, during the first penal fishing colony use of the town, fishermen privately expressed resentment as their community experienced a loss of dignity as well as increased competition over marine resources.

By the 1990s, some of the fishermen who had fled Pinochet's Pisagua had returned. To this day, they continue to harbor a loathing for the disruption and violence enacted in Pisagua in a personal way that the majority of migrant fishing families, having arrived near the end of the Pinochet era, cannot identify with. Yet these families are also largely sympathetic with the political left, having experienced the Pinochet era elsewhere. ${ }^{24}$ Several fishermen claim to see ghosts.

Regarding the anti-tourism sentiments of the political activists: the fishermen feel sympathy for the pilgrims based upon having a common exposure to Pinochet and feeling general sympathy with working-class compañeros. Nonetheless, the fishermen want the infrastructure that comes with tourism development. They maintain an attitude of indifference towards the prison's transformation into an ostensibly apolitical hotel whose owners purposely eradicate rather than commemorate past terrors. Unlike human rights activists who see the hotel as sacrilege, the fishermen are willing to accept it and the attendant tourism that promises a chance to diversify income. If anything, the fishing community wants to be tied closer to the core economy, even at the expense of not fully honoring certain ghosts. They are playing off the hopes of the town's Junta de Vecinos for transforming their fishing and loco-smuggling backwater into a more convenient place to live, one with more infrastructure and broader opportunities for livelihood, utilities, medical attention, and schooling.

\section{Junta De Vecinos: Grassroots Hope For A Balance}

The president of Pisagua's Junta de Vecinos, Rafael, is a member of Diputada Antonella Sciaraffia Estrada's political party, and was there negotiating as the liaison between Pisagua and the regional and national level government when she came to town. Rafael is a Santiago intellectual who once worked as President Allende's television cameraman. The town's ability to petition government predominantly rests on Rafael's role as the charismatic leader of the Junta; he is an essential bridge between the Pisagua community and the political core. Besides Rafael and his wife, the Junta's few active members are several of the fishermen's wives. Pisagua also has a fishing syndicate leader, but there is currently little interaction between the Junta and the fishing syndicate leader.

24. Arrests and killings took place all over Chile. However, Pinochet used Pisagua as one of his first and main concentration camps. 
Though the Junta de Vecinos is small, Rafael considers its role in the community to be of extreme importance, and he regards himself as very willing and able to represent the community.

Rafael says that he and his wife have settled in Pisagua in order to create a "paradise". Their goal is to transform what they see as an unorganized migrant group, squatting in the former concentration camp, into an empowered community of fishing families within a thriving tourist economy in the spectacular arid coastal landscape. ${ }^{25}$ They are banking on getting the government to carry out its plans to surmount the physical isolation and bring in basic infrastructure.

\section{The Main Conflicts}

\section{The Prison Hotel as a Symbol of the Struggle over Space and Identity: Government vs. Political Activists}

Although the majority of Chileans speak of their lingering odio --hatred -- from the Pinochet period of political violence, there are tourists eager to sleep among the ghosts of prisoners purported to roam the corridors of the renovated hotel. The hotel markets itself as a ghostly thrill, yet does not discuss the prison camp aspects of Pisagua or the prison's central role in them. For Chilean tourists, Pisagua is synonymous with Pinochet terror, but foreigners can remain in the dark. When foreign tourists inquire about the prison's history, the owners simply claim to know nothing. ${ }^{26}$

Concordantly, political activists are deeply offended because the prison camp aspect of the town's history is being glossed over in the tourist literature that touts the town as only a quaint curiosity with beautiful beaches. Tourism developers are brushing over the political violence that wracked Pisagua during the political prison eras; they are revising the town's history to market their "paradise". The museum pointedly masks political history by confining its themes to the pre-Columbian Chango and the nitrate port periods.

Thus, the prison hotel is contested space between tourist interests and interests of the political left. The struggle is over consecration of place (Harvey, 1996; Meltzoff, 1997), and one can clearly see in the struggle the shifting definitions of Chile's political economy and history. Here, place-making is mobilized by the struggle over political identity and how power relations are manifested (Harvey 1993, Meltzoff 1997, Watts 1993). Preservation efforts -- including the renovation of the elegant yet deadly prison -- are "a process that converts the private visions of cultural elites into public markers of a new social order" (Flores 1995). However, in the Chilean case, the right-wing economic elite responsible for the prison hotel must face the pending repercussions of unimagined political power shifts. These shifts led to the arrest of General Pinochet and national/ international scrutiny of his human rights crimes, and gave more voice to the political activists. ${ }^{27}$ This demonstrates a political will that most Chileans doubted possible in a state where the economic elite continue to back the General. ${ }^{28}$

25. Rafael managed to buy a lookout point among the large rocks above the police station, and built his house on this spot in emulation of Pablo Neruda s seaside house in Isla Negra. He purchased the land from an absentee owner -- a man living in Iquique who came from an old Pisaguisa family.

26. Weekenders, especially from Arica, are the main customers. But during high season in the summer (November-February), Germans, French, and other European tourists stay in the hotel. 
Given the divergent interests of the local fishing community, tourism developers, and human rights activists, there is a struggle over revising Pisagua's political history to accommodate tourism and the developers' political sentiments. The contention over converting the prison into a hotel, and the town into a tourist mecca, illustrates territorialization (Greenberg 1999a and 1999b) with a twist. Multilevel tourist interests are out for securing profits in Pisagua, running counter to the interests of political activists intent on preserving their historical memories, however haunting. In the activists' eyes, commodifying the prison to turn a profit obliterates the political memories which are crystallized at this locus of military brutality. Human rights activists are resolved to hold Pisagua high as their official sacred "site of memory" (Nora 1989) in order to create the atmosphere for maintaining their story and inciting social consciousness (Jo-Frazier 1999). Hence, with the natural, historical and cultural resources of Pisagua being carved up by the varying interests, Pisagua could fall prey to the "tragedy of commoditization" (Greenberg 1999b).

\section{Government Plans: Coastal Management and Tourism vs. Fishermen}

The process of globalization has the potential to alter the community identity of the resident fishing families of Pisagua as their space becomes a tourist destination. Nonpolitical tourists from the booming city of Iquique are already beginning to break the desolation, wending their way to Pisagua on improved roads to swim, camp, and even sleep in style among ghosts in the prison hotel.

The government plan does consider ways to improve fishermen's livelihood, although fisheries development is subject to the dominant purpose of developing a tourist-based economy. Government agencies commonly overlap and compete, resulting in mismatched and uncoordinated management and development efforts (Greenberg 1999a). In Pisagua's case, the Subsecretary of Fisheries has an agenda that in practice proves subordinate to the plans of the tourist developers and associated government interests.

The fisheries agenda includes provisions for improving and stabilizing fishing income by repairing the fishing wharf and developing aquaculture, although capital improvements are yet to be seen. It aims to refocus fishermen from diving for shellfish and smuggling loco--the norm--into a more aquaculture-based fisheries that grows scallops which have the added advantage of being able to survive and even thrive during warm water El Niño events. This suspended-line aquaculture project could be less vulnerable to these environmental shifts, thus lending some economic stability to the fishermen, despite deep fluctuations in availability and prices of marketable, wild-caught marine species.

However, Pisagua's first scallop aquaculture training course in 1999 only attracted and sustained the interest of five of the fishermen - predominately the leaders. New investments of time and scarce capital intimidated most fishermen. As in community-

27. Iquique's main newspaper, Estrella, recently ran a story on 9 September 2002 about the amplification of a memorial to the disappeared of Pisagua: "Ampliar n memorial de ex prisioneros" . www.estrellaiquique.cl.

28. In the close presidential election of 1999, the rightwing contender, Lavin, campaigned on obliterating the Pinochet era past, insisting that it was in Chile s best interest to bury all hard feelings and cries for justice that included trying and punishing Pinochet himself. Shocking everyone, given the General s tight ties to the economic power elite, Pinochet was finally arrested in Chile on 1 December 2000 . 
based development projects worldwide, cooperative efforts are being viewed with skepticism given the uncertainty over who will ultimately control the project and reap its profits, if any (Parras 2001, Schroeder 1995). Reinforcing these fears, the government agency granting aquaculture concessions was refusing petitions by the training agency to harvest and sell their aquaculture product on behalf of Pisagua. It is no wonder fishermen lack faith in such projects given the tangle of government agencies and contradictory actions. Moreover, Pisagua fishermen confuse this aquaculture concession as being the same as their pending management area (MA). ${ }^{29}$ The Chilean MA -- a type of Marine Protected Area (MPA) -- grants the local fisheries syndicate marine tenure over an area for wild harvesting only (Meltzoff et al., 2002).

As in many other parts of the world that suffer from illegal harvesting and overfishing (Doeringer and Terkla 1995, McGoodwin 1990), implementation of MPAs and other comanagement approaches aim to address these problems. Government planners and managers are increasingly receptive to co-management (Parras 2001; Pinkerton 1989), yet need to prove its viability to the fishermen. Establishing an MA in Pisagua, similar to those now being established in other Chilean caletas, would grant local fishermen marine tenure rights, but also add economic costs and conservation-based responsibilities (Meltzoff et. al. 2002). The Subsecretary of Fisheries sees the MA system as a novel management tool which will resolve Chile's rampant illegal loco harvesting. By allowing loco harvesting within a MA, fishermen could avoid breaking the law, or at least provide management data through the monitored sale of $l o c o .{ }^{30}$ If loco are able to fully recuperate after the 1997-98 El Niño event, loco harvested with or without a MA will continue to predominate the Pisagua fisheries, even in the face of overexploitation.

If Pisagua forges ahead with tourism development, the granting of property titles is of foremost importance in determining which way benefits will flow (Weaver 1996). In order to be able to sell more of the land lots and encourage investment in renovation, plans involve determining ownership of the abandoned buildings where a number of fishing families have squatted. Determining land titles would enable sale and greatly increase property values. Renovation would push the rent or cost of buying beyond the means of the current inhabitants. This is a familiar phenomenon in places where outsiders, attracted by natural and architectural beauty, buy up real estate and renovate (Meltzoff, 1997). This often results in the displacement of local families.

This same pattern could befall Pisagua's population. One common reason fishermen cite for having migrated to Pisagua is that the town has been open to settlers living freely. There is a competitive edge that Pisagua's fringe lifestyle offers those who remain relatively free of debts and modest regarding their economic demands. Families that make up Pisagua's artisanal fisheries sector have depended upon this economic flexibility to expand and contract with the ebb and flow of the interrelated economic, political, and environmental tides. The families are following a standard strategy in which small-scale producers, by limiting capital inputs to a bare minimum rather than extending capital

29. The Chile Norte Project at Universidad Arturo Pratt, Iquique, surveyed marine resources in Pisagua, investigated the potential for establishing a MA, and submitted paperwork in 2000 for its implementation.

30. Fishermen will present loco as having been legally extracted from within the MA, even when they originate from outside the MA. 
outlays and incurring debt, are better able to survive periods of fishery lows (Doeringer, Moss, and Terkla 1986).

This vital pattern is under pressure to change. Without land titles, squatters could be pushed out. If rent is no longer free and people begin to pay utilities bills, increased debts could restrict fishermen's ability to subsist during hard times, such as those ushered in by intense El Niño events. Investors already envision vacation development along the seaside by the fishing wharf. This prime shore front is where an enclave of families over a ten-year period have been sinking their fishing profits into building cinder block homes. They now run the risk of having their homes bulldozed.

By 1999, a regional plan was underway for building 40 government-subsidized houses further up the hillside on government land. In order to be eligible, a person must not have title to property anywhere else in Chile. These new houses come with land titles, and as such have been presented as a boon to the fishing families who hold no title to their present abodes. However, some of them could not afford the necessary down payment, or did not wish to extend themselves with added costs that they avoided by living outside the official system. Most do not foresee that electric bills combined with legal ownership are about to replace low cost living. This trend has repercussions on household economic decisionmaking (Durrenberger 1996).

The government's housing relocation program is one way that the fishermen can be easily moved out of prime coastal locations as development proceeds. Fishermen's concepts of what constitutes a good place to live has been driven by economic flexibility the reverse of prime coastal real estate.

Meanwhile, the Junta is receiving petitions from outsiders wishing to build summer houses in Pisagua. Some of these outsiders are Hijos de Pisagua--Children of Pisagua-people from Pisaguisa families who left long ago and those whose past generations lived here. The Hijos are prominent among both the buyers and sellers of Pisagua real estate. Periodically, bus loads of Hijos de Pisagua come from Iquique and Arica for day trips to visit their old family haunts, maintaining ties with each other and the land.

Overall, implementation of all facets of the government plan will set up the delicate counterplay between increasing desirability of living in Pisagua and an escalating cost of living related to renovation and new services. How these play out will determine the future stability of the fishing community. Thus, the fishermen face an identity crisis as Pisagua is subject to the forces of globalization.

The fishermen, however, do not seem to see this impending crisis; why they don't is an issue clarified through historical perspectives at the local and global levels. At the local level, the fishermen's history is one of perseverance. The impermanence of Pisagua's everchanging identity has not blocked the lifestyle of this fluid fishing community. Though decidedly a marginalized community, their marginalization has remained constant in the face of change, and they find no reason to believe that new shifts could drastically alter their livelihood.

However, historic insight at the global level tells us that under current circumstances, there is a strong possibility for further marginalization, if not a complete ousting of the fishing community from Pisagua. The onset of tourism has a nearly undefeated record in its history of ousting or supplanting fishing cultures. Tourism-based infrastructure has repeatedly increased migration to more isolated outposts by people looking for work. Ironically, if Pisagua does become less secluded through the process of incorporation into the mainstream Chilean economy, and thus a more comfortable and convenient place to live, there could be an influx of new migrant fishermen into town. This, in turn, would 
increase fishing effort in a currently stressed fishery. Finally, other global patterns could also alter Pisagua fishermen's identity, such as (1) the collapse of fisheries due to stock declines and (2) the rise of aquaculture techniques as a primary ocean-based livelihood.

Pisagua's impending shifts in social structure also carry a number of identity threats to Pisagua's fishermen. Well-paid, alternative employment opportunities risk creating class differences among the fishermen if new jobs become available, thus breaking apart the community (Streicker, 1997). Family members now working in the cities might be able to return to find local work, but migration by poorer fishing families - befitting of Pisagua's current profile - might be tempered by Pisagua's increasing household costs.

Currently, Chilean artisanal fishing culture cultivates a sense of independence which runs so deep as to even applaud deft evasion of the law (Meltzoff et al., 2002). Squatting and loco smuggling practices in Pisagua have reinforced such a mindset. Its fishermen have been living in an essential free-for-all: working with scant management in Pisagua's rich isolated waters, moving and migrating according to the whims of the loco, their fringe lifestyle embodies the alluring elements of lawlessness. However, planned civility will be at odds with any deep-seated identities along this vein. Aquaculture, though more sustainably promising than fishing, does not embody the same independent, romantic elements as fishing. Loco smuggling practices are likely to be hampered in the future due to higher if the community becomes more populous, since the principal way smugglers are caught is if someone local informs on them. Additionally, impending marine tenure rights and MA regulations intend to further restrict the fishermen's ability to follow migrating marine stocks. Such conflicts may ultimately affect the fishermen's willingness and ability to function in Pisagua's envisioned community - it is obvious that they currently do not personify a "destination resort" mentality. Such factors may be at play in the government's paper-tiger attitude towards the incorporation of the fishermen into a tourism economy: officials may question the likelihood for success in a tourist-based economy of a group they may already perceive to be untamable.

\section{Black Horses}

“...one does not see what is all-too-visible; one does not note what is 'always there'. Things are noticed when they disappear or go bust: they must fall first out from the routinely "given" for the search after their essences to start and the questions about their origin, whereabouts, use or value to be asked."

(Zygmunt Bauman, 2001)

Given the extent of intervention through government planning and management, the prospects of continuity and cultural conservation (Meltzoff 1997; LiPuma and Meltzoff 1997) for both the fishing community and the political activists are on precarious footing. Their positions are especially vulnerable in the face of plans for tourism. But the question remains as to how much change actually will be wrought by these plans. ${ }^{31}$ The government's tourism agenda is fragile. Its fragility lies in having to surmount five key obstacles: (1) Pisagua's physical isolation; (2) susceptibility to El Niño events and tidal waves; (3) a morass of unclear titles to real estate; (4) presence of a single charismatic

31. Despite the "Pisagua 2000" publicity campaign that ran in Iquique, the summer of 1999-2000 brought disappointingly few tourists to Pisagua. 
leader who is currently the only capable liaison between the community and government; and (5) the dependence of tourism on multilevel political and economic stability.

The key to understanding these fragilities lies in viewing them as concerns of environment and identity. Environmental considerations are historically underplayed in the literature and misunderstood in regards to their importance in effective planning and management. Vivian (1994) lists four patterns that are typical community reactions to environmental degradation: (1) changes in patterns of production and consumption by households and individuals (2) migration (3) occupational pluralism (4) collective, community efforts. In Pisagua, these reactions are at different stages; the last has barely begun. In any case, it takes little imagination to see that there is a relationship between individual/group identity issues and in the potential effectiveness of such reactions. How Pisagua's community interacts with its natural environment should be of considerable importance in tourism/fisheries plans for Pisagua, since the envisioned globalized Pisagua community will be interacting with the same environment. In this, we see the tip of the relationship between environment, identity, and globalization.

Growing recognition of the importance of identity is illustrated by the recent explosion of identity studies (Hall, 1996). Bauman (2001) has declared a new "era of identity". In his view, this era has its roots in globalization. Unlike those who see globalization as an antiidentity force, Bauman believes that identity is lubricated by the globalization process, and that, in turn, identity lubricates the globalization process (Bauman, 2001).

An espousal of this view marks the starting point from which to proceed towards the possible solutions to Pisagua's dilemmas that are offered in this paper. Our reconsideration of environment and identity begins with a look at two under utilized players in Pisagua's ongoing drama, and how their integration may be of paramount importance to the success of plans for a globalized economy in Pisagua. Such an integration could ultimately allow resilience in the face of political and environmental fluctuations, and at the same time clarify and even serve identity needs of Pisagua's current stakeholders.

\section{Silent Lord Behind the Scenes: Environment's Role in the Conflict}

“... how human societies manage nature-territorialize it and fight for control over or rights to pieces of it... [determines] what happens to such territorializations as resources enter into global arenas."

(Greenberg, in preparation)

Globalization is normally viewed in academic circles as anti-local; however, for globalization to actually work may require the maintenance of local knowledge, culture, resources and practices. Globalization is based upon efficiency - upon the maximum utilization of environmental spaces in response to their unique characteristics. Even in a globalized world, the geography itself remains non-uniform, with countless niches composed of unique combinations of human/environmental interactions and physical and perhaps biological characteristics. Various niches automatically elicit various human behavior strategies, and thus various cultural concepts and practices. Indeed, one of anthropology's first gifts was to show us how to compare similarities and differences in specific lifestyle approaches based upon similarities and differences in respective environments. 
In essence, just as political and economic shifts matter, environmental change offers an important key to why different groups end up with different practices. Environment shapes the community as much as the community shapes the environment. To not consider community identity is to not consider the environment; to destroy the identity is to destroy clues to effective functioning within that environment. That one generalized application will not work in all environmental situations is obvious. That local practices tend to reflect niche-specific applications that do work should be equally obvious.

However, management and planning practices often continue to ignore the obvious. In Pisagua's case, knowing how to best function within Pisagua's coastal environment is still the realm of the local fishermen - despite possible technology. Their attitudes reflect concepts of life that are copacetic with their particular environment. Reflecting this, local fishing decisions in Pisagua remain at odds with top-down model-driven management decisions inspired by non-local ecologists/biologists:

“...loco size limits have been set based on scientific data for Chile's southern loco, which grow far larger than their northern counterparts. That the legal size for loco is uniform along the entire coastline of Chile creates a disparity, making it difficult to harvest loco legally in the far northern Regions I and II where loco hardly attain legal size." (Meltzoff et al., 2002, p. 91).

Fishermen scoff equally at the government's MA plan, which allows individuals the right to legally harvest loco only within specific, designated marine tenure areas. With dour amusement, the fishermen note that loco migrate in an out of these management areas in unpredictable patterns, making a law-abiding fisherman's chance for success a gamble left up to the arbitrary actions of government officials responsible for issuing rights to marine tenure areas. It is no wonder that the idea of government-sponsored fisheries management for loco has become something of a national joke.

It is easy to understand environmental considerations as instrumental to the plight of the fishermen. It is perhaps less apparent that the environment - as a combination of climate change, ocean characteristics, geographical location, and the desert oasis aspect of Pisagua - is what primarily determines and ultimately plays a vicissitudinal ongoing role in the success and endurance of Pisagua's tourism industry. Cruz-Torres (2001) notes this under considered role of nature, and stresses that environmental issues cannot be separated from political, social, and economic issues.

In Pisagua, such issues are good reasons to uphold the importance of the fishermen's experiential wisdom as major components of tourism management in a fluctuating physical environment. No other group is better positioned to safely, reliably, and efficiently offer such tourist services as sport fishing trips, tours to the sea lion nursery, and supplies of available local seafood. Such environmental aspects of Pisagua may play favorably in its potential for success as a tourist destination. In fact, El Niño events may actually provide Pisagua with benefits in the tourism market, since its coast is sheltered from the brunt of El Niño's rough waters and is less affected by resulting shoreline detritus as compared to Iquique in the south.

Other environmental elements are against Pisagua. Its beaches and secluded location, despite newly paved roads, simply cannot compare to Iquique's long sandy expanses complete with casinos, night clubs, and major airport. Whether or not paradise-seeking tourists will be willing to make the trip is thus in question. In addition, more tourism in Pisagua could further degrade Pisagua's existing environmental attractions. As Weaver has 
pointed out, “...road building would increase tourism, lead to overcrowding, [and] overuse of a delicate ecosystem..."(Weaver 1996, p.37). Although his case deals with Northern Mexican forestry, a parallel can be drawn with Pisagua, where improved roads can threaten Pisagua's delicate coastal desert ecosystem by increasing tourism and straining resources. King (1997) notes that the emergence of tourism has negative impacts on existing fisheries, even those with histories of sustainability, due to increased demand for fresh local seafood. In Pisagua, this increase could be the death knell for loco. Whether marine stocks exist to support an extensive sport fishing practice is also questionable. In the final analysis, Pisagua's coastal environment may hold too few natural resources to support itself solely on a traditional, tourism-based commoditization of such resources, even in the short term.

However, as the environment holds one key to the successful incorporation of Pisagua into the global economy, so must a deeper analysis of Pisagua's environmental niche be made, including an historical look at the practices Pisagua's environment has supported in the past. In regards to tourism, environmental and cultural uniqueness is what gives a tourist location its competitive niche. If tourism is to boom, Pisagua must have something special to offer. Indeed, the desert prison history of Pisagua may be as valuable as its sequestered ocean setting and colonial past in final considerations of the town's prospects as a tourist destination. Pisagua's mixed identity is a natural expression of its landscape. Approaches to tourism based upon its uniqueness will be reviewed later.

\section{Player of Prominence: Role of the Junta in Conflict and Solution}

The Junta de Vecinos with its charismatic leader has a vision for improving the lot of Pisagua's fishing community that depends upon tourism and the government plan. The Junta aspires to attain infrastructure developments that would link Pisagua to the core Chilean economy via the establishment of a tourist-based economy that would bring economic benefits to the fishermen. Yet, this vision runs far beyond that of the fishermen who cling to what they know, the sea. Without a strong local leader capable of negotiating with those at the top of the policy-making ladder (Weaver 1996), Pisagua's fishing community would end up accepting their fate, rather than directing it.

Social researchers emphasize the importance of a strong recognized "leader" for successful grassroots campaigns that connect local to national government (Stout, 1996; Bergmann, Hurson, and Russ-Eft, 1999). Certainly, it can be argued that there is a critical role for charismatic leaders in local communities facing globalization, as indicated by their presence in such situations (Meltzoff \& LiPuma, 1986; Meltzoff, 1995; Meltzoff \& Schull, 1998). Rafael, with his political ties and concomitant empathy for both the fishermen and the political activists, may be the man for Pisagua. Rafael was an instrumental, behind-the-scenes player when electrical lighting arrived in Pisagua. For years, the fishing families had placed a hand-lettered sign out on the highway, LUZ PARA PISAGUA -- light for Pisagua -- calling for their town's electrification. After having their pleas for such infrastructure ignored, the timing was finally ripe, given economic and political circumstances. In 1999, the community finally received illumination. Rafael views his involvement in Pisagua's electrification as an effective way of using the fishermen's sign to help "plug" them into the core economy -- thus giving them a sense that their voice is being heard. Yet few of the fishermen understand or credit Rafael's connection to Pisagua's new lighting.

Unlike many of the fishermen who do not see trade-offs inherent in the increase of tourism in Pisagua, the Junta members via Rafael acknowledge this possibility. 
Nonetheless his group maintains support for the government plan. They see tourism as the reason why the government is willing to invest capital in Pisagua. Rafael uses this as a method to carry out his private political agenda to aid the people by creating paradise out of a political inferno mirrored by the desert landscape. In regards to new government housing, the Junta supports the idea of fishermen investing in title, though Rafael understands that they may need to shift their livelihood to obtain the necessary capital for rent. Rafael feels that there is good in local economic diversification: with added income possibilities, the fishermen can maintain an ocean-based livelihood in Pisagua as sport guides and fishermen with financial support from alternate tourist and temporary construction employment opportunities.

The Junta and its plans embody many traits that may allow Rafael's ultimate goal to be realized. Housing title and a diversified economy that could support incoming family members may engender a stronger sense of community identity, which is essential for effective collective action (Johnson, 2001). That the Junta's core working members are women is no surprise, since social research shows a pattern of effectiveness in grassroots programs for reaching through to women (Dejene \& Crummey, 1992; Fonjong, 2001). Conveniently, the resulting gender empowerment (Herda-Rapp, 2000) proves an effective mechanism for instigating general community participation and local involvement in policies affecting the community (Pettersen and Solbakken, 1998; Scheyvens, 1988; Creevey and Edgerton, 1997), including co-management processes (Pomeroy et al., 2001). While women's voices at the government level often lack power (Lee, 2000; Fonjong, 2001), the Junta De Vecinos, with Rafael as their leader and the hopeful involvement of the fishermen themselves, is well outfitted for success.

The basic motive of the Junta reflects a similar desire among all players -- the fishermen, the Junta, and the government tourism and fisheries management programs - to provide more economic security to the Pisagua fishermen. However, questions remain as to how enthusiastically the fishermen will champion Rafael's Junta version of paradise and the attendant identity shifts it requires. Rafael -- as a local elite who arrived with the major influx of fishermen a decade ago -- has never fished, so may have difficulty leading the fishermen in a co-management effort. Additionally, there is an inherent danger in community reliance upon a single individual, whose eventual absence may splinter collective structure (Katon et al., 2001).

Finally, there is still a hole in the Junta agenda concerning interests of the political activists. Rafael is motivated by imagining a community "paradise" at a site haunted by political memories of a concentration camp. As he builds alliances with non-local powers, he risks dishonoring this aspect of Pisagua, since core development money expresses scant sympathy for the memories of political activists. If the Junta truly desires to transform the heart of Pisagua, it must carefully negotiate this duel between competing versions of paradise.

\section{Tourism as Solution}

"President Videla--who is remembered as the architect of his birthplace, La Serena--could not resist constructing an elaborate prison whose two-story administrative front section is of Oregon pine in Georgian neoclassical style. The wood for the project was gleaned from old ships..."

(Meltzoff, fieldnotes, 1999) 
A government-sponsored survey of Pisagua as a fishing base concludes that if fishing ended, $90 \%$ of the fishermen would change occupation, and that $80 \%$ would leave (Programa Chile Norte, 1998:35). This statistic only reassures planners and developers who want local labor to shift into the tourist industry, or at least vacate prime coastal real estate and colonial edifices still in disrepair. Nonetheless, there remains a tug-of-war over place between tourist interests and those of human rights activists concerned with retaining Pisagua as a symbol of sacred ground.

The development efforts may have far-reaching and varied effects on the community of fishing families that neither the Junta nor the planners have weighed. Given the "tragedy of commoditization" (Greenberg 1999b), policies advantageous to the promotion of tourism could seriously neglect or damage fishermen's interests, as well as the sacred and politicized aspect that the human rights activists want to honor.

Pisagua's success with tourism is linked to economic well-being and political stability at multiple levels -- from regional to international. During Chile's present period of political democracy and prosperity, government development policies are focusing on stimulating private investment outside urban centers, in the periphery. The development plan for Pisagua is already starting to furnish the town with basic infrastructure -- the object being to foster a tourist-based economy. Electricity has recently arrived, and roadwork is well underway to facilitate access between Pisagua and the outside world.

Tourism as the prison hotel would have it seeks to bury political ghosts by expunging Pisagua's representation as a place of political imprisonment. At the expense of political memory, the hotel and tourist interests aim to forge a new identity for Pisagua as a touristic "paradise". This desire is compatible with that of developers. Pisagua's space is poised to take on a new meaning as a picturesque town ready for renovation.

However, as a seaside beach resort, Pisagua risks remaining hidden within the looming shadow of Iquique to the south. Iquique's better beaches, established infrastructure, and airport leaves Pisagua facing the grim economic situation of remaining a secondary destination due to its peripheral location and less-than-equivalent infrastructure and amenities (Wall, 1996). Moreover, a reliance on ecotourism, as previously mentioned, risks further degradation of an already degraded fishery.

Truthfully, Pisagua's location between two major transportation hubs (Arica to the north and Iquique to the south) may lend itself to tourism; however, studies show gross differences in outcome between well and poorly planned tourism (Wall, 1996). In Pisagua, the problem is that planners are using an approach to tourism that is somewhat shortsighted. Through its rehousing program, the government is falling prey to a traditional tourism pitfall which ends up highlighting the contrast of material poverty - developers gobble up and build in the most scenic areas, while locals remain segregated yet salient in nearby shanties. Further, Pisagua's tourism developers are following an old Chilean tradition that envisions cultural and racial differences as "obstacles to be overcome, not opportunities to be seized" (Wali, 1995). In doing so, they neglect a basic, textbook tenet of modern tourism which emphasizes the preservation of all available cultural landscapes (Stadel, 1996). In short, government planners are following outdated visions of tourism and economy.

In order to solidify its future, current tourism research shows that Pisagua will likely benefit most from a diversification of its touristic potentials in order to attract regional, national, and international interests, as well as a diversification of the its economy in nontourism-based forms. With this in mind, the voices of both the political activists and the fishermen become instrumental components of Pisagua's future. 
Regarding the desires of the political activists, there is no need to wipe out the political symbolism of Pisagua for the purpose of tourist development: diversification is the key here, and heritage tourism, based on the town's fascinating history as a political prison, may be the answer - not just for the purposes of tourism, but for the purposes of the political activists as well. Modern tourism management textbooks point out the socioeconomic benefits of pilgrimage tourism as part of a total, integrated tourist system, in which the integration of multiple types of tourism is the key to stability and success (Inskeep, 1991). Cohen (1992) notes how time transforms the pilgrim/pilgrimage center relationship into a tourist/tourism center relationship, as the memory of past triumphs and tragedies slowly become history lessons. Eade (1992) also notes the pilgrim/tourist relationship, and points out how tourism is used to serve the identity needs for pilgrims through services of a communicative/educational nature. In this, heritage tourism is a mechanism for globalization's unapparent role as a revitalizer of older identities (Streicker, 1997).

In exploring this possible utilitarian role, it is worth noting that there is some history of Chilean involvement in maintaining cultural identity, as exemplified by the acquisition of funds from the Inter-American Foundation for the purpose of cultural expression projects (Wali, 1995). Pisagua's hotel-prison serves as a reflection of cultural symbols and incarnate representation of identity struggles on a social and political level. Such incarnations can also be seen in Key West's San Carlos sanctuary (Meltzoff, 1997), Germany's Berlin Wall, and, most recently, the former New York World Trade Center - all pilgrimage sites in which tourism now serves a commemorative/identity role. In Pisagua's case, activists at the very least would like the tourism developers to somehow pay homage to the hotel's true past; reasons above present both parties with good reason to commodify Pisagua's recent history. Meanwhile, the mass grave and Pisagua's historic desert battlefield can continue to serve their current uncommodified, commemorative roles.

With heritage tourism removing some of the pressure from ecotourism, Pisagua is more likely to make a successful transition to a globalized economy. Chilean government officials have noted the conflict of interests between conservation and improving caleta's livelihood (Meltzoff et al., 2002); in doing so, they ultimately note the unsustainable nature of fishing as a sole source of livelihood for the fishermen in the new economy. Planners instead envision fishermen benefiting directly from tourism by spending less time fishing and allocating more time catering to ecotours, such as by guiding sport fishermen and making boat trips to the sea lion nursery. Fishermen could also do part-time construction and service-industry work. In addition to these possibilities, the potential role for aquaculture as an alternative and substantial source of income cannot be understated.

Such opportunities for occupational multiplicity are advocated by Allison \& Ellis (2001) as a "livelihoods" approach to fluctuating marine resources: it allows fishermen to maintain an ocean-based identity while simultaneously providing financial alternatives and relieving pressure from fisheries stocks at critical moments. Given new household costs such as rent and electricity, and the ultimate impact tourism and migration will likely have on competition for marine resources, it is uncertain how the fishing community could otherwise survive economic and environmental downturns.

Yet, it is also unclear how successful the government will be in creating tourist-based alternatives to fishing, and how resilient the fishing community's social system will prove. Here, the Junta De Vecinos becomes instrumental as a way of uniting the fishing community into a collective voice that might carry weight in the government plans actively revamping Pisagua. This voice should consider the role that heritage tourism can 
play in maintaining the fishermen's own livelihood. Herein lies a potential for unifying the fishing community with the political activists. A successful unification would strengthen all voices.

The fishing community and its potential collective voice should recognize the practical utility of stabilizing their families in Pisagua. This will allow fishermen and their families to continue fishing as well as serve as a source of service workers and knowledgeable ecotourism guides. Incorporating more family members into Pisagua's coming development would simultaneously provide stability to both industry and families. Industry benefits include workers who are knowledgeable and comfortable with the area, as well as more settled - thus less of a turnover rate. Note that married men in specific are often considered superior as workers to single men (Gibson, 1999). Families will benefit through financial stability from diversity: slumps in fishing may be offset by tourism; slumps in tourism may be offset by fishing and aquaculture practices.

Regarding the potential benefits of aquaculture, a collective voice in Pisagua might also help facilitate the incorporation of aquaculture into Pisagua's fishing/tourism industry, and involve the fishermen in development of effective fisheries management techniques overall. On this note, it is worth mentioning Saharuddin's (2001) recent assessment of marine tourism, aquaculture, and capacity building as a viable three-part approach to sustainable maritime development.

\section{Adaptive Approaches To Fisheries Management}

"They outrageous, them rules...Who live in this cider house? Who grinding up those apples, pressing that cider, cleaning up all this mess?... Who just plain live here, just breathing in that vinegar?...Well, someone who don't live here made those rules. These rules ain't for us. We the ones supposed to make our own rules, and we do, every single day..."

(from the movie "Cider House Rules", 1998)

Pisagua's commodity chain has included: international nitrate port, railroad terminus, national prison, fish meal production plant, and now, budding tourist destination. Throughout its history, Pisagua's political economy has often typified the top-down model in which government and private interests enjoy the greatest profits, while locals are left with whatever trickles down (Weaver 1996). However, Pisagua's boom and bust pattern will be found highly undesirable to regional and national interests once Pisagua becomes tied to Chile's core economy. Thus, it is now in the government's best interest to finally develop a steady economy in Pisagua. Such an economy will likely include ecotourism, fishing, and aquaculture approaches, and will thus require some form of resource management in Pisagua.

Traditional top-down management, however, tends to fall short in such situations, due to ineffective regulations, low compliance to those regulations, and high monitoring and enforcement costs. The resulting failure of this approach is recently evident in Pisagua. When the 1997-98 El Niño event caused a number of anomalies in north Chile's marine environment, fishermen migrated between caletas in response to resource availability and market conditions. Such behavior is common in fisheries communities, in which labor tends to migrate in and out as a function of prevailing economic and political forces (LiPuma and Meltzoff 1997) and is deemed a necessary, practical response to mobile or 
fluctuating fish stocks (Allison \& Ellis, 2001). The new government fisheries directives, however, make it illegal for fishermen to migrate between regions. The loss of flexibility makes following the law economically impossible. Thus Chilean fisheries management lacks enforceability.

Under their own management, local people are found to be selective in their incorporation of new knowledge and technology into their livelihood planning and economic planning, and tend follow the creative leadership of their own entrepreneurs (Salisbury, 1970). Fishermen's reasoning is simple: management is useful if it produces. Around the world, management initiatives commonly fail by not following this logic. Instead, unapplied scientific and economic principles are usually given more weight than local knowledge in policy creation. In Namibia, for example, top-down "sustainable development" agendas are now blamed for desertification in the area - for generations, locals had been successfully working and coexisting with the natural, intermittent flood/ drought patterns (Sullivan, 2000). This "economics first, society last" view of development has the disadvantage of seeing the elements in the reverse order of their reallife importance (Meltzoff and LiPuma, 1986). Future policy makers should be "keen to consider the long-term humankind-sensitive interest above the rational interests" (Vallega, 2001, p. 399), lest their decisions result in equally devastating blows to the environment, the society, and future economic prospects.

Accordingly, Pisagua's best solution may be some form of co-management, in which those who directly depend on the resource share responsibility for managing that resource (Pinkerton, 1989). However, it is important to note that co-management practices to date have fallen short of their community-based management goals. Many programs have ended up being paper tigers in which local incorporation was ultimately down played. Some critics claim that a lack of the necessary community elements - fishermen participation, local leadership, available financial capital, enforceable management, longterm government cooperation and support, and property rights to resources, among others - have undermined co-management efforts (Pomeroy et al., 2001). Other critics blame the lack of a strong civil element in the local community (Jentoft, 2000; Holm, Hersoug, and Ranes, 2000).

For Pisagua to address such needs will require refocusing upon co-management's original vision of community participation. Co-management does imply a more formal power structure: some taking away of control from the individual, and some routinization and standardization (Jentoft, 2000). To serve this end, a strong, organic form of local social organization may be prerequisite to success (Wali, 1995). Indeed, studies have shown that community-based economics and grassroots organizations tend to result in greater individual compliance to ecologically-oriented directives when rules are administered under community management (Coleman, 1994). A study of local organizations in Haiti, Peru, Mali, and Nepal showed that "in marginalized rural areas, local organization seems to take hold more firmly with a process approach that permits people to define their own priorities and organize themselves around appropriate solutions and structures." (Pettit, 2000).

Further support for the importance of focusing upon community identity comes from the Grassroots Development Framework, developed as a result of three decades of work in Central and South American by the Inter-American Fund. The Framework considers a focus upon individual, family, and local identity and cohesiveness to be fundamental to the success of sustainable development (Ritchey-Vance, 1998). The bridge linking identity and sustainability is capacity building, which is shown to be an effective means of 
facilitating individual and community empowerment (Pomeroy et al., 2001) and subsequently increasing local community involvement in the management and development of coastal and ocean resources (Howe, 2001; Smith \& Potts, 2001). As an adjunct to infrastructure capital and technological capital, it is a concept of "social capital", defined by McClenaghan (2000) as a "social learning process [education, training, development of community organizations, community meetings, etc.] which serves to empower individuals and to involve them as citizens in collective activities aimed at socioeconomic development."

Regarding the usefulness of global concepts, Allison \& Ellis (2001) cite the need to focus on the actual local benefits of science-based knowledge and strategies as viable mechanisms to sustainable fisheries management. With this in mind, specific capacity building strategies should use arithmetic and visual learning techniques that are equally comprehensible to both scientists and fishermen (Meltzoff et al., 2002). Scientists may benefit from spending a day on the water with the fishermen in order for both parties to understand how different training and management strategies might apply. Ultimately, capacity building sessions should be an intra-community process - locals mentoring locals. It is important to stress that effective capacity building must be interactive - local concepts are as useful to scientists and policy makers as translated global scientific concepts are to locals. Whereas technology improves efficiency in catch, processing, storage, by-catch, and boat upkeep (Allison \& Ellis, 2001), the practical management of chaotic fisheries may best be based upon the fishermen's daily in-the-water observations and knowledge (Wilson \& Kleban, 1992).

Day-to-day observations, in an ideally adaptive management plan, are communicated back to policy makers and scientists; in cooperation with local fishermen, they adjust policies and predictions accordingly. For instance, the flying crab is known to appear to divers in Pisco/Paracas, Peru, as a harbinger of a strong El Niño event (Meltzoff, ongoing fieldwork). This information may be as useful to the fishermen and their subsequent behavior as it is to policy makers/scientists and their subsequent policies/predictions. Such a case exemplifies the importance of tapping local knowledge (Wali, 1995), especially for the purpose of control of the decision-making process (Noble, 2000; Meltzoff et al., 2002). The incorporation and primacy of local knowledge in the decision-making process ideally through fishermen's direct involvement in long-term and short-term policy making - is key here. Only this way can policy discrepancies between theory and local practice be mediated. Such mediation also allows for enforceable regulations - laws that can be economically and socially observed. Community-created and monitored enforcement codes may increase compliance through the effects of peer logic and pressure.

Thus, the concept of adaptive management procures a new generation of management tools. Such tools include the incorporation of fishermen's daily observations in policy and decision-making processes, use of locally comprehensible arithmetic and visualization techniques in capacity building sessions, two-way capacity building, and the evolution of intra-community organizations and leadership for mentoring and monitoring (McManus \& Meltzoff, in progress). These tools can form the base of adaptive strategies which allow subsequent management policies the flexibility to be reshaped as needed to fit time- and space-specific characteristics arising from a triangle of political, economic, and environmental change. 


\section{Conclusion}

We have seen why Pisagua, as a fragile, isolated environment, will likely require a multiplicity of approaches in order to prove successful. Fisheries management, aquaculture, ecotourism, and heritage tourism are all likely to play interrelated roles in a successfully globalized Pisagua economy - making Pisagua's plight an overall issue of town management. Positioned at the heart of this plight, having the greatest stake in Pisagua's future, are the voices of Pisagua itself - the fishermen, the Junta, and the political activists. Their cooperation may be instrumental in achieving a collective voice that serves their personal needs and, ultimately, the needs of Pisagua at political, economic, and environmental levels.

\section{References}

Abler, Marjane.

1990. Breaking the Iron Bonds: Indian Control of Energy Development. Kansas: University Press of Kansas.

Allison, Edward H. and Frank Ellis.

2001. The livelihoods approach and management of small-scale fisheries. Marine Policy. 25: 377-388.

Bauman, Zygmunt.

2001. Identity in the globalizing world. Plenary lecture, 6th EASA conference, Krakow, July 2000. Social Anthropology Vol. 9 (2), 121-129.

Bergmann, Horst, Kathleen Hurson, and Darlene Russ-Eft.

1999. Everyone a Leader: A Grassroots Model for the New Workplace New York: John Wile and Sons, Inc.

Bryant, Raymond L.

1992. Political Ecology: An Emerging Research Agenda in Third-World Studies. Political Geography, Vol.11(1), January 1992, 12-36.

Cohen, E.

1992. Pilgrimage centers concentric and eccentric. Annals of Tourism Research 19(1):33-50

Coleman, Daniel A.

1994. Ecopolitics: Building a Green Society. New Brunswick, New Jersey: Rutgers University Press.

Constable, Pamela and Arturo Valenzuela.

1991. A Nation of Enemies: Chile Under Pinochet New York: W.W. Norton and Company

Creevey, L. and J. Edgerton.

1997. Evaluation of the impacts of grassroots management training on women in India.

Canadian Journal of Development Studies. Special Issue SI 18: 645-672

Cruz-Torres, Maria.

2001. Local-level responses to environmental degradation in Northwestern Mexico. Journal of Anthropological Research 57(2): 111-136.

Dejene, A. and D. Crummey.

1992. Environment, famine, and politics from Ethiopia - A view from the village.

Politics and the Life Sciences 11(2): 269-270 
Dobson, Jane W.

1999. Balancing the Books on Conservation and Development: Transient Corporate Investment in Golfito, Costa Rica. Journal of Political Ecology 79(6):79-101.

Doeringer, Peter B., Philip I. Moss, and David G. Terkla.

1986. The New England Fishing Economy: Jobs, Income, and Kinship. Amherst: University of Massachusetts Press.

Doeringer, P. B. And D. G. Terkla.

1995. Troubled Waters: Economic Structure, Regulatory Reform, and Fisheries Trade. Toronto: University of Toronto Press.

Durrenberger, E. Paul.

1996. Gulf Coast Soundings: People and Policy in the Mississippi Shrimp Industry. Kansas: University Press of Kansas.

Eade $\mathrm{J}$.

1992. Pilgrimage and Tourism at Lourdes, France Annals of Tourism Research 19(1)18-32.

Fonjong, L.

2001. Fostering women's participation in development through non-governmental efforts in Cameroon. Geographical Journal. 167(3):223-234.

Greenberg, James.

1999a. Territorialization, Globalization, and Dependent Capitalism in the Political Ecology of Fisheries in the Upper Gulf of California. Prepared for Culture, History, Power, Nature: Ecologies for the New Millennium. Biersack, A. and Greenberg, J., eds. [in preparation]

1999b. The Tragedy of Commoditization: Political Ecology of the Colorado River

Delta's Destruction. Research in Economic Anthropology 19:133-149.

Gobernación Provincial de Iquique.

1998. Informe de Inversión Pública Pisagua, July 1998.

Hall, Stuart.

1996. Who needs "identity"? In Stuart Hall and Paul du Gay (eds.) Questions of cultural identity. London: Sage

Harvey, David.

1996. Justice, Nature and the Geography of Difference. Cambridge, MA: Blackwell Publishers Inc.

Herda-Rapp, A.

2000. Gender identity expansion and negotiation in the toxic waste movement. Sociological Quarterly. 41(3):431-442.

Holm, Petter, Bjørn Hersoug, and Stein Arne Rånes.

2000. Revisiting Lofoten: Co-Managing Fish Stocks or Fishing Space? Human Organization 59(3): 353-364.

Howe, Vicki.

2001. Local community training and education in southern Tanzania - a case study. Marine Policy 25(6): 445-455.

Hughes, Robert.

1988. The Fatal Shore: The Epic of Australia's Founding. New York: Vintage Books. Inskeep, Edward.

1991. Tourism planning: an integrated and sustainable development approach. Van Nostrand Reinhold NY

Vol.8 2001

Journal of Political Ecology 
Jentoft, S.

2001. The community: a missing link of fisheries management. Marine Policy 24: 5359.

Jo-Frazier, Lessie.

1998. Memory and State Violence in Chile: A Historical Ethnography of Tarapaca, 1890-1995. Ph.D. Dissertation. University of Michigan.

1999. "Subverted Memories": Countermourning as Political Action in Chile. In Mieke Bal, Crew and Spitzer (Eds.) Acts of Memory. University of New England Press.

Johnson, C.

2001. Community formation and fisheries conservation in Southern Thailand Development and Change. 32(5): 951-974

Katon B., Pomeroy R., Ring M., and Garces L.

1998. Mangrove rehabilitation and coastal resource management of Mabini-Candijay: a case study of fisheries co-management arrangements in Cogtong Bay, Philippines. Fisheries Co-management Research Project Working Paper no. 33 Manila: ICLARM. p. 1-149.

King, T.D.

1997. Folk management among Belizean lobster fishermen: Success and resilience or decline and depletion? Human Organization 56(4): 418-426.

Lee, Ewy.

2000. Gender and political participation in Hong Kong. Asian Journal of Women's Studies. 6(3): 93-114

LiPuma, Edward and Sarah Keene Meltzoff.

1997. The Crosscurrents of Ethnicity and Class in the Construction of Public Policy. American Ethnologist 24(1):114-131.

McClenaghan, $\mathrm{P}$.

2000. Social Capital: exploring the theoretical foundations of community development education. British Educational Research Journal. 26(5): 565-582.

McGoodwin, J. R.

1990. Crisis in the World's Fisheries. Stanford: Stanford University Press.

McManus, Liana Talaus and Sarah Keene Meltzoff.

[in preparation]. An Adaptive Management Approach to Coastal Management.

Meltzoff, Sarah Keene.

1995. Meltzoff, S.K. Marisquadoras of the Shellfish Revolution: The Rise of Women in Co-Management on Illa de Arousa, Galicia. Journal of Political Ecology. 2: 22-38.

1997. Beneath the Veneer of Paradise: The Struggle over Cuban Ethnic Identity and Place in Key West. Ecumene 4 (2):139-160.

Meltzoff, S.K. and Edward LiPuma.

1986. Hunting for Tuna and cash in the Solomons: A rebirth of artisanal fishing in Malaita. Human Organization 45(1): 53-62.

Meltzoff, S.K. and Jennifer Schull.

1999. Ethnic Struggle over Land and Lobster: Miskito Indians' Cultural Conservation. Special Volume of Culture and Agriculture. Vol. 21, No 3:10-18.

Meltzoff, Sarah Keene, Wolfgang Stotz, and Yair Gibrán Lichtensztajn.

2002. Competing Visions for Marine Tenure and Co-Management: Genesis of a Marine Management Area System in Chile. Coastal Management. 30: 85-99 
Neruda, Pablo.

1991. I Accuse. In: Canto General, Jack Schmitt translation. Berkeley: University of California Press. p.199.

Neumann, R.P.

1992. Political Ecology of Wildlife Conservation in the Mt. Meru Area of Northern Tanzania. Land Degradation and Rehabilitation, (3): 85-98.

Noble, B.F.

2000. Institutional criteria for co-management. Marine Policy 24: 69-77.

Nora, Pierre.

1989. Between Memory and History. Representations 26:7-25 (Spring).

Palsson, G.

1994. Enskillment at sea. Man 29(4): 901-927.

Parras, Diane A.

2001. Coastal Resource Management in the Philippines: A Case Study in the Central Visayas Region. Journal of Environment and Development. 10(1):80-103.

Pettersen, L.T. and H. Solbakken.

1998. Empowerment as a strategy for change for farm women in western industrialized countries. Sociologia Ruralis 38(3): 318-+

Pettit, J.

2000. Strengthening local organization - "Where rubber hits the road". Ids Bulletin: Institute of Development Studies. 31(3): 57-+

Pinkerton, E.

1989. Cooperative Management of Local Fisheries: New Directions for Improved Management and Community Development. Vancouver: University of British Columbia Press.

Pomeroy, Robert S., Brenda M. Katon, and Ingvild Harkes.

2000. Conditions affecting the success of fisheries co-management: lessons from Asia. Marine Policy 25: 197-208

Programa Chile Norte.

1998. Diagnóstico para el Fomento Productivo Pesquero Caleta Pisagua, I Región.

Ritchey-Vance, Marion.

1998. Widening the lens of impact assessment. In Jutta Blauert and Simon Zadek (eds.) In Mediating Sustainability: Growing Policy From the Grassroots. Hartford Connecticut: Kumarian Press.

Saharuddin, Abdul Hamid.

2001. National ocean policy - new opportunities for Malaysian ocean development. Marine Policy 25(6): 427-436.

Salisbury, Richard F.

1970. Vunamami: Economic Transformation In A Traditional Society. Los Angeles: University of California Press.

Scheyvens, R.

1988. Subtle strategies for women's empowerment - Planning for effective grassroots development. Third World Planning Review. 20(3): 235-253.

Schroeder, Richard A.

1995. Contradictions Along the Commodity Road to Environmental Stabilization: Foresting Gambian Gardens. Antipode 27(4): 325-342. 
Smith, Hance D. and Jonathon Potts.

2001. Editorial. "Special Issue on Ocean Governance and Capacity Building.." Marine Policy 25(6): 389-390.

Stadel, Christopher.

1996. Divergence and Conflict, or Convergence and Harmony? In: Lynn C. Harrison and Winston Husbands (eds.) Practicing Responsible Tourism New York: John Wiley and Sons

Stout, Linda.

1996. Bridging the Class Divide. Boston: Beacon Press.

Streicker, Joel.

1997. Remaking race, class, and region in a tourist town. Identities 3(4) pp. 523-555.

Sullivan, Sian.

2000. Getting Science Right, Or Introducing Science In The First Place? In: Sian Sullivan and Philip Stott (eds.) Political Ecology: Science, Myth, and Power. New York: Oxford University Press.

Teitelboim, Volodia.

1975. La Semilla en la Arena. Editorial de Arte y Literatura, La Havana.

Vallega, Adalberto.

2000. Ocean governance in post-modern society - a geographical perspective. Marine Policy 25(6): 399-414

Vivian, J.

1992. Environmental Degradation and Social Integration. Briefing Paper 3, World Summit for Social Development, November 1994. Geneva: United Nations Research Institute for Social Development

Wali, Alaka.

1995. Living with the land: Ethnicity and Development in Chile. In: Kleymeyer, Charles David (ed.) New Cultural Expression \& Grassroots Development Boulder Colorado: Lynne Rienner Publishers.

Wall, Geoffrey.

1996. One Name, Two Destinations: Planned and Unplanned Coastal Resorts in Indonesia. In: Lynn C. Harrison and Winston Husbands (eds.) Practicing Responsible Tourism New York: John Wiley and Sons

Watts, M.J.

1993. Struggles over Land, Struggles over Meaning. In: R. Golledge (Ed.) A Ground for a Common Search. Santa Barbara: UC Santa Barbara Press.

Weaver, Thomas.

1996. Mapping the Policy Terrain: Political Economy, Policy, Environment, and Forestry Production in Northern Mexico. Journal of Political Ecology. Vol. 3: 37-68. Wilson, J.A., and P. Kleban.

1993. Practical implications of chaos in fisheries: Ecologically adapted management. Maritime Anthropological Studies 5: 67-75.

\section{Acknowledgements}

Fieldwork in Pisagua, Chile was carried out by Sarah Keene Meltzoff through the generosity of grants from NOAA's Human Dimensions of Climate Change program and the National Science Foundation's NMIA. Michael Lemons and Yair G. Lichtensztajn have been great M.A. graduate students in our marine Affairs and Policy program. Special 
gratitude goes to another former student, Toni Parras, for her clear insights and editing expertise. I would especially like to thank Guillermo Ross-Murray Lay-Kim for sharing his deep knowledge of the region. Oscar Romero has kindly provided unique and invaluable perspectives. Ricardo Vicencio and Maritza Gallardo of Chile Norte imparted their insights and gave generously of their time. I am also indebted to Pisagua's political pilgrims and fishing families for bringing warmth and life to this field experience. Many thanks to Lessie Jo-Frazier for her thoughtful contributions.

\section{Abstract}

Caught between the sea and one of the world's driest deserts, Pisagua's coastal desert landscape is being transformed by the ways people utilize its natural isolation and rich protected waters. Periodically, these waters are altered by El Niño events. As distinct stakeholders -- fishermen, political activists, government planners, tourists and developers -- appropriate the site, their competing voices and identities alter the patterns of resource use. The most consistent resident group is a small number of fishermen, who have been willing to forego modern infrastructure to live in Pisagua's harsh natural, political, and economic isolation. Because of this isolation, three separate national administrations have utilized the town as a political prison. The fishermen visualize political ghosts roaming the wooden ruins of this once thriving nitrate port. Developers today, however, aim to sanitize local political history in order to create a tourist "paradise", and are being aided by a government plan to incorporate Pisagua into the core Chilean economy. Political activists, who use Pisagua as a pilgrimage site to indemnify the horrors of the past, protest this plan as one of political sacrilege. The plan also has concrete ramifications for the fishing families of Pisagua, who not only struggle with scarcity during major El Niño events, but now face encroaching tourism as globalization encompasses their space. The resident grassroots community leader has proffered additions to the plan that directly benefit the community. He is a former political activist with visions of a community-based "paradise" that would incorporate the marginal voices of the fishermen. We discuss his role as part of an approach which views identity and livelihood as practical and essential elements of any economically viable management plan. We examine shifting identity roles in light of the Pisagua plans, and frame our discussion within the context of three overlapping climate changes: economic, political, and environmental. This lays the foundation for a suggested adaptive management strategy that serves the economic needs of Pisagua through a recognition of the importance of stakeholder identity and livelihood.

Key words: Pisagua, Chile, political ecology, ethnography, space and place, identity, livelihood, environment, El Niño, climate change, political activism, pilgrim, globalization, fisheries, migration, tourism, MPA, co-management.

\section{Resumé}

Attrapé entre la mer et un des déserts le plus sec du monde, l'étendue désertique de la cote de Pisagua est en train de transformation suite à l'exploitation de son isolation naturelle et de ses eaux riches et protégées. De temps en temps, ces eaux sont altérées par El Niño. Comme les différents groupes intéressés, les pêcheurs, les activistes politiques, les planificateurs gouvernementaux, les touristes et les développeurs, s'approprient de l'endroit, leurs voix et identités compétitrices réarrangent l'usage des ressources. Les résidents et participants les plus stables sont un petit nombre de pêcheurs, qui ont choisi 
d'accepter l'isolation naturelle, politique et économique et le manque d'infrastructure de Pisagua. À cause de l'isolation de l'endroit, trois administrations consécutives ont utilisé la ville comme prison politique. Les pêcheurs imaginent les esprits des prisonniers traversant les ruines en bois de ce qui était une fois un port prospère pour les nitrates. Les développeurs d'aujourd'hui, cependant, veulent assainir l'histoire locale politique afin de créer un paradis touristique, et ils sont aidés dans ce but par un plan gouvernemental d'incorporer Pisagua dans l'économie Chileen. Les activistes politiques, qui utilisent Pisagua comme site de pèlerinage pour commémorer les horreurs du passé, protestent ce plan comme un sacrilège politique. Le plan a aussi des implications réales pour les familles des pêcheurs qui luttent contre le manque de pêche pendant les périodes El Niño mais doivent maintenant lutter aussi contre le tourisme et le globalisme qui viennent prendre leur espace. Un activiste local a proposé des modifications au plan qui bénéficieraient la communauté. Il a été un activiste politique qui avait des rêves d'un paradis à l'échelle de la communauté qui incorporerait les voix marginales des pécheurs. Nous discutons son rôle comme part d'une approche qui prendrait l'identité et mode de vie comme éléments essentiels de tout plan d'aménagement économique viable. Nous regardons les changements d'identité dans la lumière du plan pour Pisagua, et nous mettons notre discours dans le contexte de trois changements climatiques : économique, politique, et environnementale. Ceci établit la fondation pour une stratégie pour l'adaptation d'un plan qui servirait les besoins de Pisagua à travers la reconnaissance de l'importance de l'identité et la mode de vie de chaque groupe intéressée.

Mots clefs: Pisagua, Chile, écologie politique, ethnographie, espace et place, identité, mode de vie, environnement, El Niño, changement de climat, activisme politique, globalization, industrie de pêche, migration touristique, MPA, coaménagement.

\section{Resumen}

Atrampado entre el mar y uno de los desiertos más secos del mundo, el paisaje del desierto costero de Pisagua está siendo transformado por las maneras que la gente utiliza su aislamiento natural y las aguas ricas protegidas. Periódicamente, estas aguas son alteradas por los eventos de El Niño. Mientras que distintos grupos con intereses opuestos- pescadores, activistas políticos, planificadores del gobierno, turistas y promotores inmobiliarias -- se apropian del sitio, la competencia entre sus voces e identidades alteran los patrones del uso de recursos naturales. El grupo residente que han aguantado el lugar por más tiempo es un pequeño número de pescadores, que han estado dispuestos a renunciar la infraestructura moderna para vivir en el aislamiento natural de Pisagua, y también a enfrentar sus ásperas condicciones políticas y económicas. Debido a este aislamiento, tres administraciones nacionales separadas han utilizado la comunidad como una prisión política. Los pescadores ven los fantasmas políticos que vagan en las ruinas de madera de esto puerto que antes prosperaba del nitrato. En la actualidad, promotores inmobiliaras, sin embargo, quieren esterilizar la historia política local para crear un paradise turístico, y están siendo ayudados por un plan del gobierno para incorporar a Pisagua a la base de la economía de Chile. Los activistas políticos, que utilizan a Pisagua como sitio del peregrinaje para indemnizar los horrores del pasado, protestan este plan como uno sacrilegio político. El plan también tiene ramificaciones concretas para las familias de pescadores de Pisagua, que luchan no solamente con la escaséz durante los eventos importantes del El Niño, sino también contra el turismo y los procesos de 
globalización que estan usurpando su espacio. El lider residente de la comunidad de raiz ha propuesto unas adiciones al plan del gobieno que beneficirarian directamente a la comunidad. Él es un ex-activista político con visiones de un "paraíso" basado en la comunidad que incorporaría las voces marginales de los pescadores. Discutimos su papel como parte de un acercamiento en que la identidad y sustento estan vistos como elementos prácticos y esenciales para cualquier plan de manejo que sea económicamente viable. En luz de los planes para el desarrollo de Pisagua examinamos los cambios en papeles de la identidad, y encuadriamos nuestra discusión dentro del contexto de tres cambios traslapados del clima económico, político, y ambiental. Esto establece la fundación para una estrategia adaptante sugerida de la administración que sirva a las necesidades económicas de Pisagua por medio de un reconocimiento de la importancia de identidad y sustento por los grupos que tienen intereses en el futuro de la comunidad.

Palabras claves: Pisagua, Chile, ecología política, etnografía, espacio y lugar, identidad, sustento, ambiente, El Niño, cambio del clima, activismo político, peregrino, globalization, industrias pesqueras, migración, turismo, MPA, co-manejo. 